\title{
PENGARUH PREFERENSI RESIKO, LITERASI EKONOMI, PENGETAHUAN GALERI INVESTASI TERHADAP MINAT INVESTASI MAHASISWA FAKULTAS EKONOMIKA DAN BISNIS
}

\author{
Rine Gesta Erawati Supriyanto \\ e-mail: rinegesta@gmail.com \\ Endah Andayani \\ e-mail: endahandayani@unikama.ac.id \\ Auliana Farrabanie Al Arsy \\ e-mail:auliana@unikama.ac.id
}

(Program Studi Pendidikan Ekonomi, Fakultas Ekonomika dan Bisnis, Universitas Kanjuruhan, Malang)

\begin{abstract}
This study aims to determine the effect of Risk Preference, Economic literacy and Investment Gallery on the investment interests of Economics and Business Faculty students. (This type of research uses quantitative research methods using multiple linear regression. The population in this study were students of the 2015 Kanjuruhan Malang Faculty of Economics and Business, amounting to 412 people. with a research sample of $25 \%$ of the population of 103 students. The data obtained was analyzed with the help of SPSS version 22.00 for Windows. Based on the calculation results, it is known that: (1) There is an influence of Risk Preference, Economic literacy and Investment Gallery on the investment interest of Economics and Business Faculty students. (2) There is no Risk Preference Effect on investment interest in Economics and Business Faculty students. (3) There is an Influence of Economic Literacy on the investment interest of the Economics and Business Faculty students (4) There is an Investment Gallery Effect on the investment interest of the Economics and Business Faculty students. The results of multiple linear regression analysis showed that the $F$ value of 24.771 with a significance level of $0.000<0.05$, it can be said that Risk Preference (X1), Economic Literacy (X2), and Knowledge of Investment Gallery (X3) have simultaneous or joint effects. equal to Investment Interest $(Y)$.
\end{abstract}

Keywords : Risk Preference, Economic Literacy, Investment Gallery, Investment Interest

\begin{abstract}
Abstrak: Penelitian ini bertujuan untuk mengetahui pengaruh Preferensi Resiko, literasi Ekonomi dan Galeri Investasi terhadap minat investasi mahasiswa Fakultas Ekonomika dan Bisnis. Jenis penelitian menggunakan metode penelitian kuantitatif dengan menggunakan regresi linier berganda. Populasi dalam penelitian ini adalah mahasiswa Universitas Kanjuruhan Malang Fakultas Ekonomika dan Bisnis angkatan 2015 yang berjumlah 412 orang. dengan sampel penelitian 25\% dari populasi yang berjumlah 103 Mahasiswa. Berdasarkan hasil perhitungan, diketahui bahwa: (1) Terdapat pengaruh Preferensi Resiko, literasi Ekonomi dan Galeri Investasi terhadap minat investasi mahasiswa Fakultas Ekonomika dan Bisnis. (2) Tidak ada Pengaruh Preferensi Resiko terhadap minat investasi mahasiswa Fakultas Ekonomika dan Bisnis. (3) Terdapat Pengaruh Literasi Ekonomi terhadap minat investasi mahasiswa Fakultas Ekonomika dan Bisnis (4) Terdapat Pengaruh Galeri Investasi terhadap minat investasi mahasiswa Fakultas Ekonomika dan Bisnis. Hasil analisis regresi linier berganda diketahui nilai $F$ hitung sebesar 24.771 dengan tingkat signifikansi 0,000 <0,05, maka dapat dikatakan bahwa Preferensi Resiko (X1), Literasi Ekonomi (X2), dan Pengetahuan Galeri Investasi (X3) memiliki pengaruh secara simultan atau bersama-sama terhadap Minat Investasi (Y).
\end{abstract}

Kata kunci : Preferensi Resiko, Literasi Ekonomi, Galeri Investasi, Minat Investasi 


\section{PENDAHULUAN}

Pendapatan digunakan untuk memenuhi suatu kebutuhan agar dapat bertahan hidup. Sumitro (2007) pendapatan merupakan jumlah barang dan jasa yang memenuhi tingkat hidup masyarakat, pendapatan yang dimiliki oleh setiap jiwa disebut dengan pendapatan perkapital dimana pendapatan perkapital menjadi tolak ukur kemajuan atau perkembangan ekonomi. Kebutuhan utama kita adalah konsumsi. Konsumsi terdiri dari sandang, pangan, dan papan. Setelah memenuhi kebutuhan tersebut, maka kemungkinan uang yang tersisa akan digunakan untuk kesenangan maupun dialokasikan kepada sesuatu kebutuhan yang dianggap akan memberikan profit kepada kehidupan yang akan mendatang, kebutuhan itu disebut investasi.

Investasi adalah penanaman modal atau penentuan uang dengan akumulasi aktiva dengan suatu harapan mendapatkan keuntungan pada masa depan. Martalena dan Malinda (2011:1) investasi merupakan bentuk penundaan konsumsi masa sekarang untuk memperoleh konsumsi di masa yang akan datang, dimana didalamnya terkandung unsur resiko ketidakpastian, sehingga dibutuhkan kompensasi atas penundaan tersebut. Investasi pada kalangan mahasiswa dapat dilakukan jika mahasiswa mempunyai minat dalam investasi. Minat investasi muncul ketika mahasiswa mempunyai selera dalam hal itu. Khairani (2013:186) minat diartikan sebagai kehendak, keinginan atau kesukaan. Pengertian ini memberikan makna bahwa minat sebagai suatu keinginan terhadap sebuah objek dan tentunya setelah timbul minat, maka seseorang akan melakukan aktivitas.

Salah satu yang menjadi pertimbangan investasi adalah Preferensi resiko. Preferensi resiko merupakan sebagai pengambilan keputusan dimana seseorang mahasiswa memutuskan untuk berinvestasi apabila mereka mampu menanggung resiko di dalam investasi. Mereka sudah paham resiko apa saja yang didapat pada saat berinvestasi. Resiko yang dimaksud adalah risiko spekulasi (speculative risk) yang kemungkinan dapat memperoleh keuntungan atau menimbulkan kerugian. Risiko spekulasi merupakan pilihan yang sadar dan dalam keadaan yang terkontrol.

Pertimbangan lainnya adalah literasi ekonomi merupakan kemampuan untuk menggunakan konsep dasar ekonomi dan cara berpikir kritis dalam pembuatan keputusan ekonomi. Literasi ekonomi dapat membuat seseorang menjadi cerdas dalam mengelola sumber daya ekonomi untuk mencapai kesejahteraan dengan cara mengaplikasikan konsep ekonomi tersebut. Selain itu, literasi ekonomi menjadi sangat penting untuk membuka pengetahuan tentang biaya/manfaat suatu barang dalam aktivitas ekonomi. Permasalahannya mahasiswa masih belum bisa membuat konsep ekonomi itu sendiri dan mahasiswa belum sepenuhnya memahami pengetahuan yang sudah diterapkan di matakuliah yang ada mereka mempelajarinya kurang sungguh-sungguh oleh karena itu literasi ekonomi menjadi pertimbangan keputusan investasi dengan pengetahuan yang didapatkan.

Pertimbangan yang terakhir adalah pengetahuan Galeri merupakan Sasaran sebagai langkah untuk menjangkau kelompok yang berpendidikan agar dapat lebih memahami dan mengenal pasar modal. Peran Galeri Investasi sebagai One stop student aktivities pasar modal di dunia akademisi merupakan salah satu sarana pembelajaran yang dapat menjadi sebuah kekuatan untuk mencerdaskan bangsa. Melalui laboratorium pasar modal yang menyediakan real time data untuk belajar menganalisa aktivitas perdagangan saham, diharapkan dapat menjadi jembatan menuju penguasaan ilmu pengetahuan beserta prakteknya di Pasar Modal, sehingga perguruan tinggi dapat menghasilkan masyarakat akademisi yang memahami teori beserta prakteknya. Tetapi pada kenyataannya mahasiswa masih ada yang belum pernah masuk ke galeri investasi karena tidak tau 
maksud dari galeri investasi itu sebenarnya untuk apa, dengan adanya kerjasama ini diharapkan dapat saling memberikan manfaat bagi semua pihak sehingga penyebaran informasi pasar modal tepat sasaran serta dapat memberikan manfaat yang optimal bagi mahasiswa, praktisi ekonomi, investor, pengamat pasar modal maupun masyarakat umum di daerah dan sekitarnya baik untuk kepentingan sosialisasi dan pendidikan/edukasi pasar modal maupun untuk kepentingan ekonomi atau alternatif investasi.Selain itu mahasiswa masih kurang dalam pengetahuan Galeri investasi jadi jarang mahasiswa yang masuk di Galeri investasi universitas Kanjuruhan Malang. Peneliti ini mempunyai tujuan untuk melihat seberapa besar mahasiswa yang sudah mempunyai pandangan untuk memenuhi kebutuhan dimasa yang akan datang.

\section{TINJAUAN PUSTAKA}

\section{Minat}

Slameto (2008), Minat adalah sesuatu rasa lebih suka dan rasa ketertarikan pada suatu hal atau aktivitas, tanpa adanya pembahasan. Sedangkan Kotler (2012 : 228) Mendefinisikan minat adalah suatu keinginan yang muncul dari dalam diri seseorang atau yang diberikan seseorang pecetus dalam keputusan. Menurut schiffman dan kanuk (2008 : 486) Mendefinisikan minat sebagai kualitas motivasi yang merupakan proses dorongan yang menyebabkan tingkah laku meskipun tidak memberikan arah setepat - tepatnya dari tingkah laku tersebut. Beberapa pendapat para ahli diatas dapat disimpulkan bahwa pengertian minat adalah rasa ketertarikan, perhatian, keinginan lebih yang dimiliki seseorang terhadap suatu hal, tanpa ada dorongan.

\section{Investasi}

Investasi dapat didefinisikan sebagai suatu komitmen atas sejumlah dana dalamsuatu periode dalam rangka mendapatkan pembayaran masa depan. (Tandelilin, $2010: 2$ ). Jenis-jenis investasi menurut Martalena dan Malinda (2011:2), Investor dapat melakukan investasi dalam berbagai jenis aset, antara lain real assets dan financial assets.

Jadi, Investasi sangant beragam bentuknya mulai dari investasi langsung dan tidak langsung. Pada umumnya mahasiswa mengetahui bahwa berinvestasi pasti akan mengeluarkan biaya yang sangat besar dan mahasiswa masih belum begitu faham tentang investasi langsung dan tidak langsung dimana bahwa sekarang investasi langsung didomisi oleh dosen dan masayarakat sekitar padahal jika dilihat untuk berinvestasi tidak harus mengeluarkan uang hingga puluhan juta atau milyaran, dengan melakukan investasi ratusan rupiah bias untuk melakukan investasi di Galeri investasi di area Universitas.

\section{Minat Investasi}

Tendelilin (2010:2) minat investasi adalah komitmen atas sejumlah dana atau sumber daya lainnya yang dilakukan pada saat ini dengan tujuan memperoleh sejumlah keuntungan dimasa yang akan dating. Pada dasarnya tujuan melakukan investasi adalah untuk menghasilkan sejumlah uang guna meningkatkan kesejahteraan investor.

Martalena dan Malinda (2011:1) investasi merupakan bentuk penundaan konsumsi masa sekarang untuk memperoleh konsumsi di masa yang akan datang, dimana didalamnya terkandung unsur resiko ketidakpastian, sehingga dibutuhkan kompensasi atas penundaan tersebut.

\section{Preferensi Resiko}

Preferensi Resiko merupakan sebagai kecenderungan seorang individu untuk memilih hal beresiko Resiko Mahasiswa pasti ingin memperoleh keuntungan dalam berinvestasi pada suatu barang tertentu. Namun, dalam berinvestasi saham bentuk apapun pasti ada resiko yang terkandung didalamnya. Resiko yang diangap oleh mahasiswa dapat beruapa capital loss atau justru mendapat keuntungan. Besarnya tingkat resiko yang bersedia ditanggung oleh investor satu dan lainnya tidaklah sama, walaupun kepribadian investor tersebut sama (Sembel dan Sembel dalam Putra, 2011 


\section{Literasi Ekonomi}

Menurut Pardey \& Bhattacharya (2012: 3) melek ekonomi adalah kemampuan untuk menggunakan konsep ekonomi untuk membuat keputusan tentang penghasilan, tabungan, pengeluaran dan mengalokasikan uang. Hal ini diperjelas oleh pendapat dari Organization for Economic Literacy (OEL) yang menegaskan bahwa melek ekonomi tidak hanya meliputi pemahaman konsep dasar ekonomi dan fakta ekonomi, tetapi juga tentang kemampuan berpikir kritis yang mendukung cara berpikir ekonomi yang benar. Dengan kata lain, melek ekonomi melibatkan pengetahuan dan penerapan teori-teori ekonomi yang mendasar dalam mengambil keputusan tentang sumber daya yang terbatas.

\section{Pengetahuan Galeri Investasi}

Galeri Investasi Bursa Efek Indonesia (BEI) adalah sarana untuk memperkenalkan Pasar Modal sejak dini kepada dunia akademisi serta sebagai pengenal dalam melakukan investasi. Galeri Investasi BEI berkonsep 3 in 1 yang merupakan kerjasama antara BEI, Perguruan Tinggi dan Perusahaan Sekuritas diharapkan tidak hanya memperkenalkan Pasar Modal dari sisi teori saja akan tetapi juga prakteknya. Kedepannya melalui Galeri Investasi BEI yang menyediakan real time information untuk belajar menganalisa aktivitas perdagangan saham, diharapkan dapat menjadi jembatan menuju penguasaan ilmu pengetahuan beserta prakteknya di pasar modal. (IDX 2017 Online)

\section{METODE PENELITIAN}

Penelitian ini menggunakan pendekatan kuantitatif, yang memiliki sejumlah ciri - ciri yang membedakannya dengan penelitian jenis lainnya. Penelitian Kuantitatif merupakan jenis penelitian yang menekankan pada aspek pengukuran secara objektif terhadap fenomena social, semua informasi atau data yang diperoleh diwujudkan dengan angka dan analisis yang digunakan adalah analisis statistik.

Jenis Penelitian ini termasuk dalam peneliatian ex-post-facto, Karena dimana variabel - variabel bebas tersebut telah terjadi dimana peneliti memulai degan mengobesvasi hubungan yang terlihat terhadap suatu variabel terikat. Penelitian ini ditujuakan untuk mengetahui pengaruh Preferesi Resiko, Literasi Ekonomi, dan Pengetahuan Galeri Investasi terhadap minat Investasi

Melihat permasalahan yang ada dalam penelitian ini, maka metode yang digunakan adalah regresi linier berganda, pengauh antar variabel yang ditelitidan dijelaskan. Regresi linier berganda adalah suatu metode statistic umum yang digunakan untuk meneliti pengaruh anatar variabel terikat degan variabel bebas. Regresi linier berganda bisa mengandung dua atau lebih variabel independen. Analisis regresi pada dasarnyabertujuan untuk mengetahui seberapa besar pengaruh anatara empat variabel, jika diantaranya dapat pengaruh yang signifikan

Variabel bebas dalam penelitian ini adalah Preferesi Resiko, Literasi Ekonomi, dan Pengetahuan Galeri Investasi. Sedangkan variabel terikatnya adalah minat Investasi. Tujuan penelitian ini adalah untuk mengetahui pengaruh antara variabel bebas dengan variabel terikat baik secara terpisah maupun bersama-sama

Penelitian ini populasinya adalah mahasiswa Universitas Kanjuruhan Malang Fakultas Ekonomika dan Bisnis angkatan 2015 yang berjumlah 412 orang. Sample peneliti mengambil $25 \%$ popolasi untuk menjadikan sample yaitu 103 orang. Dimana teknik pengambilan sample menggunakan systematic sampling dimana prosedur ini berupa penarikan sample dengan cara mengambil setiap kasus (nomor urut) yang kesekian dari daftar populasi. 


\section{PEMBAHASAN}

Penelitian ini menggunakan model regresi linier berganda, karena variabel bebas yang diteliti lebih dari satu. Pengolahan data menggunakan SPSS versi 22 for windows. Hasil analisis data sebagai berikut

Uji t

Uji t digunakan ntuk menguji signifikan pengaruh secara parsial variabel independen yang terdiri dari Preferensi Resiko (X1), Literasi Ekonomi (X2), Pengetahuan galeri investasi (X3) dengan variabel dependen yaitu minat investasi $(\mathrm{Y})$. Hasil uji t pada penelitian ini adalah sebagai berikut :

\begin{tabular}{|lllll|}
\multicolumn{5}{c}{ Coefficients $^{\mathrm{a}}$} \\
\hline 1 & Model & T & Sig & Keterangan \\
& (Constant) & 4.590 & .000 & \\
& Preferensi_ & 1.789 & .077 & Tidak \\
& $\begin{array}{l}\text { Resiko_X1 } \\
\text { Literasi_Ek }\end{array}$ & 2.272 & .025 & Signifikan \\
& & & \\
& onomi_X2 \\
Galeri_Inv & 3.123 & .002 & Signifikan \\
& estasi_X3 & & & \\
\hline
\end{tabular}

Dependent Variable : Minat_Investas_Y

Sumber : SPSS 22 for windows

Hipotesis penelitian untuk menguji hipotesis kedua $\left(\mathrm{H}_{2}\right)$ adalah sebagai berikut: berdasarkan hasil analisis diperoleh nilai thitung $=1,789$ sedangkan tabel 1.659 atau thitung $>$ tabel dengan nilai sig 0,077 lebih besar dari 0,05 maka $\mathrm{H}_{02}$ diterima dan $\mathrm{H}_{2}$ ditolak, artinya Preferensi Resiko (X1) tidak memiliki pengaruh yang signifikan terhadap Minat Investasi Mahasiswa Fakultas Ekonomika dan Bisnis

Hipotesis penelitian untuk menguji hipotesis ketiga $\left(\mathrm{H}_{3}\right)$ adalah sebagai berikut: berdasarkan hasil analisis diperoleh nilai thitung $=2.272$ sedangkan tabel 1.659 atau thitung $>$ tabel dengan nilai sig. 0,025 lebih kecil dari 0,05 maka $\mathrm{H}_{0} 3$ ditolak dan $\mathrm{H}_{3}$ diterima artinya Literasi Ekonomi $\left(\mathrm{X}_{2}\right)$ memiliki pengaruh yang signifikan terhadap Minat Investasi Mahasiswa Fakultas Ekonomika dan Bisnis

Hipotesis penelitian untuk menguji hipotesis keempat $\left(\mathrm{H}_{4}\right)$ adalah sebagai berikut: berdasarkan hasil analisis diperoleh nilai thitung $=3.123$ sedangkan tabel 1.659 atau thitung $>$ tabel dengan nilai sig. 0,002 lebih kecil dari 0,05 maka $\mathrm{H}_{0} 4$ ditolak dan $\mathrm{H}_{4}$ diterima artinya pengetahuan Galeri Ivestasi $\left(\mathrm{X}_{3}\right)$ memiliki pengaruh yang signifikan terhadap Minat Investasi Mahasiswa Fakultas Ekonomika dan Bisnis

\section{Uji F}

Uji F digunakan untuk menguji secara simultan hingga dapat diambil hipotesis pertama $\left(\mathrm{H}_{1}\right)$ yaitu variabel bebas Preferensi Resiko (X1), Literasi Ekonomi (X2), dan pengetahuan galeri investasi (X3) terhadap Minat investasi (Y). Berdasarkan hasil statistic perhitungan SPSS 22 for windows diperoleh tabel Anova yang menunjukkan uji F statistik. Berikut ini adalah tabel uji F 


\begin{tabular}{|c|c|c|c|c|c|c|}
\hline \multicolumn{7}{|c|}{ ANOVA $^{a}$} \\
\hline \multicolumn{2}{|c|}{ Model } & $\begin{array}{c}\text { Sum of } \\
\text { Squares }\end{array}$ & $\mathrm{df}$ & $\begin{array}{l}\text { Mean } \\
\text { Square }\end{array}$ & F & Sig. \\
\hline 1 & $\begin{array}{l}\text { Regress } \\
\text { ion }\end{array}$ & 935.573 & 3 & 311.858 & $\begin{array}{r}24.77 \\
1\end{array}$ & $.000^{\mathrm{b}}$ \\
\hline & $\begin{array}{l}\text { Residu } \\
\text { al }\end{array}$ & 1246.388 & 99 & 12.590 & & \\
\hline & Total & 2181.961 & 102 & & & \\
\hline
\end{tabular}

a. Dependent Variable: Minat_investasi_Y

b. Predictors: (Constant), Galeri_Investasi_X3,

Literasi_Ekonomi_X2, Preferensi_Resiko_X1

Berdasarkan tabel diatas bahwa nilai Fhitung yaitu 24.771 selanjutnya untuk pengujian hipotesis maka nilai tersebut dibandingkan dengan $\mathrm{F}_{\text {tabel }}$ pada taraf $\alpha=0,05$. Dasar pengambilan keputusan untuk pengujian hipotesis sebagai berikut: hasil tes anova diperoleh nilai $\mathrm{F}$ sebesar 24.771 dengan tingkat signifikan $0,000^{\mathrm{b}}$, karena nilai signifikan lebih kecil dari 0,05, maka, $\mathrm{H}_{0} 1$ ditolak dan $\mathrm{H}_{1}$ diterima, artinya Preferensi Resiko, Literasi Ekonomi dan pengetahuan Galeri Investasi secara simultan berpengaruh signifikan terhadap Minat Investasi Mahasiswa Fakultas Ekonomika dan Bisnis

\section{KESIMPULAN}

Berdasarkan pembahasan hasil analisis yang telah dikemukakan, maka dapat ditarik kesimpulan ada pengaruh yang signifikan secara simultan preferensi resiko, literasi ekonomi, dan pengetahuan galeri investasi terhadap minat investasi mahasiswa fakultas ekonomika dan bisnis, Tidak ada pengaruh yang signifikan secara parsial prefrensi resiko terhadap minat investasi mahasiswa fakultas ekonomika dan bisnis, Ada pengaruh yang signifikan secara parsial literasi ekonomi terhadap minat investasi mahasiswa fakultas ekonomika dan bisnis, Ada pengaruh yang signifikan secara parsial pengetahuan galeri investasi terhadap minat investasi mahasiswa fakultas ekonomika dan bisnis.

Berdasarkan hasil penelitian terdapat beberapa saran yang dapat meingkatkan minat investasi mahasiswa fakultas ekonomika dan bisnis, Literasi ekonomi dari mahasiswa fakultas ekonomika dan bisnis sudah baik, akan tetapi perlu ditingkatkan lagi supaya mahasiswa fakultas ekonomika dan bisnis bisa terus berkembang wawasan tentang berinvestasi, dengan pengetahuan yang luas, mahasiswa secara langsung akan mengaplikasikan dan menerapkan ilmu yang berkaitan dengan investasi di galeri investasi, sehingga akan berdampak kepada kemajuan mahasiswa. Preferensi resiko tidak berpengaruh terhadap minat investasi, maka dari itu perlu adanya peningkatan dan upaya sadar diri akan pentingnya melakukan investasi, supaya bisa meningkat kesejahteraan bagi mahasiswa.

Bagi Mahasiswa Fakultas Ekonomika dan Bisnis adalah Mahasiswa Fakultas Ekonomika dan Bisnis harus terus aktif dalam kegiatandi Galeri Investasi, harus ada rasa tekad yang kuat untuk memajukan kesejahteraan diri kita. Selain itu, mahasiswa juga harus memanfaatkan fasilitas yang ada pada di Galeri Investasi, seperti contoh menanamkan saham di galeri investasi sebagaimana kita belajar berinvestasi, karena dengan memanfaatkan fasilitas di galeri investasi akan muncul rasa ingin tahu yang tinggi pada diri mahasiswa tentang investasi, sehingga akan berdampak pada peningkatkan minat mahasiswa untuk berinvestasi. Bagi Galeri Investasi, Penelitian ini diharapkan dapat memberikan masukan bagi Galeri investasi yang ada di universitas kanjuruhan malang untuk meningkatkan fasilitas yang ada dengan memperhatikan aspek-aspek yang mempengaruhi minat berinvestasi. Bagi peneliti selanjutnya,Penelitian ini diharapkan dapat membantu peneliti selanjutnya 
sebagai salah satu acuan. Temuan dalam penelitian ini dapat dijadikan perbandingan untuk mengadaka penelitian yang sejenis dengan cakupan yang luas.

\section{DAFTAR PUSTAKA}

Abdul Muhid (2010), Analisis Statistik SPSS for Windows : Cara Praktis Melakukan Analisis Statistik, Surabaya : CV Duta Aksara

Bursa Efek Indonesia (2017), Analisa Perdagangan Saham, diakses pada www.idx.com

Joanna Sokolowska dan Piotr Makowiec (2017). Risk Preferences Of Individual, Investors : The Role Of Dispositional, Tendencies and Market Trends (Preferensi Resiko Investor Individu: Peran Kecenderungan Disposisional Dan Pasar Tren)

Jogiyanto (2009), Teori Portofolio dan Analisis investasi Edisi Keenam, Cetakan Pertama, Yogyakarta : PT. BPFE Yogyakarta

NCEE (2003), Test Your Own Economic Literacy. NCEE Standards in Economics diakses pada http// www.ncee.com

Paridey, Chanchala \& Bhattacharya (2012) Economic Literacy of Senior Secondary School Teacher : A Field Stud, Jurnal of all India Association for Educational Research Vol 24 No 1

Putra, Bima Ekawarna, (2011), Analisis ciri kepribadian dan Preferensi Resiko Pada Pedagang di Salatiga, Universitas Kristen Satya Wacana

Salim, Joko (2010), Cara Gampang Bermain Saham, Jakarta : Visi Media

Schiffman dan Kanuuk (2008) Perilaku Konsumen Edisi 7 Jakarta : Indeks

Selim Aren dkk (2016). Influence of Financial Literacy and Risk Perception on Choice of Investment

(Pengaruh Melek Keuangan dan persepsi Resiko Terhadap Pilihan Investasi)

Sembel R dan Sembel - Lapian V (2007), “Energizing Your Life”, Jakarta : Elex Media Kompution

Slameto (2010), Belajar dan Faktor-faktor yang Mempengaruhinya, Jakarta : Rineka Cipta

Soemitro, Rachmat (2007), Dasar-dasar Hukum Pajak Pendapatan, Jakarta : Salema Empat

Tandelilin, Eduardus, (2010), Portofolio dan Investasi Teori dan Aplikasi Edisi Pertama, Yogyakarta : Kanisius

Timothius Tandio, (2016), Pengaruh Pelatihan Pasar Modal, Return, Persepsi Resiko,Gender, dan Kemajuan Teknologi pada Minat Investasi Mahasiswa

Tullio Joppelli (2010), Economic Literacy : An International Comparison (Melek Ekonomi : Perbadingan Iternasional)

Yuanita Rahmawati (2018), Relevansi Nilai Pengetahuan Tentang Investasi dan manfaatnya bagi investor kelompok mahasiswa FEBI Lain Ponorogo. 